\title{
The Illustration of the Master
}





\section{The Illustration of the Master}

Henry James and the Magazine Revolution

\section{Amy Tucker}

Stanford University Press

Stanford, California 
Stanford University Press

Stanford, California

(C) 2010 by the Board of Trustees of the Leland Stanford Junior University. All rights reserved.

No part of this book may be reproduced or transmitted in any form or by any means, electronic or mechanical, including photocopying and recording, or in any information storage or retrieval system without the prior written permission of Stanford University Press.

Printed in the United States of America on acid-free, archival-quality paper

Library of Congress Cataloging-in-Publication Data

Tucker, Amy.

The illustration of the master : Henry James and the magazine revolution / Amy Tucker. p. cm.

Includes bibliographical references and index.

ISBN 978-0-8047-6874-0 (cloth : alk. paper)

1. James, Henry, 1843-1916-Illustrations. 2. James, Henry, 1843-1916-Criticism and interpretation. 3. Magazine illustration-United States-19th century. 4. Art and literature-United States-History-19th century. 5. Periodicals-Publishing-United States-History — 19th century. 6. Books and reading-United States-History-19th century. I. Title.

PS2124.T83 2010

$813^{\prime} .4-\mathrm{dc} 22$

2009045988

Typeset at Stanford University Press in 11/15 Bell MT 
For Steve 
